\title{
Face morphology of brazilian and peruvian populations: analysis of proportion and linear measurement indexes
}

Morfologia facial de populações brasileira e peruana: análise de índices de proporção e medidas lineares

Elaine Cristina Sousa dos SANTOS ${ }^{1}$, Diego Jesus Bradariz PIMENTEL ${ }^{1}$, Laís Lopes Machado de MATOS ${ }^{1}$, Laís Valencise MAGRI ${ }^{1}$, Ana Maria Bettoni Rodrigues da SILVA ${ }^{1}$, Marco Antônio Moreira Rodrigues da SILVA ${ }^{1}$

1 - Department of Restorative Dentistry - School of Dentistry of Ribeirão Preto - São Paulo University - Ribeirão Preto - SP - Brazil.

\section{ABSTRACT}

Objective: To compare the proportion and linear measurement indexes between Brazilian and Peruvian population through 3D stereophotogrammetry and to stablish the face profile of these two Latin American populations. Material and Methods: 40 volunteers (Brazilian $\mathrm{n}=21-10$ males and 11 females; Peruvian $\mathrm{n}=19-8$ males and 11 females) aged between 18 and 40 years (mean of $28.7 \pm 9.1$ ) had landmarks marked on the face. Then, 3D images were obtained (VECTRA M3) and the indexes of proportion and linear measurement (face, nose, and lips) were calculated. The data were statistically analyzed by One-Way ANOVA ( $\mathrm{p}<0.05$ ). Results: The proportion indexes did not reveal marked differences either between the studied populations or genders ( $p>0.05)$. The following linear measurements showed intergroup statistically significant differences: face width and height, nose width and height, upper facial height, mouth width, protrusion of the nose tip $(\mathrm{p}<0.05)$. The Brazilian females showed the smallest significant differences. Conclusions: Despite the different ethnic compositions, the Brazilian and Peruvian populations did not differ regarding the proportions of the face, nose, and lips. The differences observed in Brazilian females may be related to gender and/ or to the Caucasian heritage of the Brazilian sample.

\section{KEYWORDS}

Photogrammetry; Face; Tridimensional Image.

\section{RESUMO}

Objetivo: Comparar índices de proporção e medidas lineares da face entre amostras de populações brasileiras e peruanas por meio da estereofotogrametria 3D, a fim de estabelecer o perfil facial destas duas populações latino-americanas. Material e Métodos: 40 voluntários (21 brasileiros 10 homens e 11 mulheres; 19 peruanos -8 homens e 11 mulheres) com idade entre 18 e 40 anos (média de $28,7 \pm 9,1)$ tiveram pontos de referência marcados na face, foram então obtidas imagens 3D (VECTRA M3) e calculados índices de proporção e medidas lineares da face, nariz e lábios. Os dados foram analisados estatisticamente por meio de ANOVA One Way ( $\mathrm{p}<0,05)$. Resultados: Os índices de proporção não revelaram grandes diferenças entre as populações analisadas ou entre gêneros $(\mathrm{p}>0,05)$. As medidas lineares que apresentaram diferença significativa na análise intergrupos foram: largura e altura da face e do nariz, altura da face superior, largura da boca e protrusão da ponta do nariz (p $<0,05$ ), sendo que as brasileiras apresentaram as diferenças mais significativas em relação aos demais grupos, com medidas faciais menores. Conclusões: As populações brasileiras e peruanas, apesar das diferentes composições étnicas, não diferem quanto às proporções de face, nariz e lábios. As diferenças observadas no grupo de brasileiras podem estar relacionadas ao gênero e/ou à maior descendência caucasiana da amostra quando comparada à população peruana.

\section{PALAVRAS-CHAVE}

Fotogrametria; Face; Imagem tridimensional. 


\section{INTRODUCTION}

$\mathrm{T}$ he face is the body structure by which the human being is recognized and differentiated by the others. The populations are composed by individuals with different face patterns, which are directly influenced by factors are age, gender, ethnic composition, and previous surgical procedures. Despite of this plurality of the facial biotypes within a given population inside a geographic territory, some similar patterns can be found, especially in populations with main ethnic compositions [1].

It is important to know and compare the facial patterns of a population, as well as the characteristics that are recognized as beauty by that population, to guide surgical procedures and face recognition. Some populations are composed by different ethnicities, for example, the Brazilian population, fact that makes difficult the determination of a more frequent face pattern [2].

Many techniques have been proposed aiming to enable the analysis of the face soft tissues, among them 3D stereophotogrammetry $[3,4]$. This technique is based in a fast, noninvasive, safe method of image acquisition without exposure to radiation. Cameras placed at different angulation acquire the image and a specific software process the 3D digital image of the individual's face. This process is considered the gold standard [5].

One of the 3D image acquisition systems is Vectra M3 (Canfield Scientific, Fairfield, $\mathrm{NJ}$ ), composed by six cameras and a projector at each capsule. Initially, this system captures the images at two dimensions and posteriorly joins them tridimensional. This system enables the analysis of many body images, including the face. These 3D images can be processed, changed, analyzed and measured by a specific software. The possibility of changing the 3D image at different directions (frontal, lateral, mandibular-maxillary, maxillary-mandibular) allows many analysis of the soft tissue, such as the measurement of the linear distances, angles, areas, and volumes [4,6-8].

Othman et. al. 2014 comparatively compared through stereophotogrammetry a group of Malayan participants regarding the face harmony and disharmony. They found differences in the morphological characteristics among the experimental groups, which provided new approaches for the diagnosis and treatment of patients with unilateral cleft lip and palate [9].

Ngeow and Aljunid also used anthropometric techniques for craniofacial measurements of Malayan young adults [10]. Other authors describing 3D face analysis were Porter \& Olson, who found differences in the face proportion between African American and Caucasian American young females [11].

Though, the stereophotogrammetry analysis is not restricted to the facial analyses because each facial structure can be separately analyzed. Dong et al. focused on the morphological analysis of the nose in the Chinese population. The authors used a new method of 3D anthropometric measurement to delineate the Chinese nose shape to contribute with the plastic surgeons [12]. Yasas et al. verified the orolabial region of Chinese females and males through 3D images aiming to standardize the lip morphology and enable an adequate planning and better prognosis prior to either orthognathic surgery, lip reconstruction, or orthodontics [13].

Thus, this study aimed to compare some indexes of proportions and linear measurements of the face between Brazilian and Peruvian populations through 3D stereophotogrammetry to stablish differences and similarities between the facial profile of these two Latin American populations. 


\section{MATERIAL AND METHODS}

\section{Study design} study.

Observational, descriptive, cross-sectional

\section{Sample design}

Nineteen Peruvian (eight males and 11 females) and 21 Brazilian individuals (10 males and 11 females) were selected, totalizing 40 participants. The participants aged between 18 and 40 years (mean age $28.7 \pm 9.1$ ) and they were analyzed according to the nationality. The inclusion criteria were healthy Brazilian or Peruvian individuals with complete dentition. The exclusion criteria were individuals without sound face structures; with genetic alterations; with history of surgery, craniofacial traumas or face scars that compromise the face morphology.

\section{Ethical aspects}

This study was conducted at the Laboratory of Research in Electromyography of the Stomatognathic System (LAPESE) of the Department of Restorative Dentistry of the School of Dentistry of Ribeirão Preto (FORP) University of São Paulo (USP) (Ribeirão Preto, SP, Brazil). This study was approved by the Research Ethics Committee regarding ethical aspects (CAAE protocol no. 62044316.2.0000.5419). Prior to the study, all participants were structed regarding the objectives, procedures, benefits, risks, discomfort of the study as well as the confidentiality of data. Those who agreed in participating in the study read and signed a free and clarified consent form.

\section{Procedures}

To capture the images, we used Vectra ${ }^{\circledR}$ M3 (Canfield, NJ, USA). This system settings were: geometric resolution of $1.2 \mathrm{~mm}$ (triangle edge length), 3.5 milliseconds capture time, intelligent flash units (on-board modular), stereophotogrammetry technology, floor stand, stool, coupled to Dell ${ }^{\circledR}$ computer, in which the images were processed. The software settings were: "Face Sculptor ${ }^{\circledR}$ ", RBX ${ }^{\circledR}$ Image Processing, VECTRA ${ }^{\circledR}$ 3D Analysis Module, Mirror ${ }^{\circledR}$ Photo File $\AA$, and Mirror Photo Tools ${ }^{\circledR}$.

The Vectra ${ }^{\circledR}$ M3 had $180 \mathrm{~cm}$ height, $122 \mathrm{~cm}$ width, and $56 \mathrm{~cm}$ length; six cameras divided into three modules: one central and two laterals. The stool position was set at $112 \mathrm{~cm}$ from the posterior area of the device. The room to store the device should have $168 \mathrm{~cm}$ length $\mathrm{x} 147 \mathrm{~cm}$ width, to allow the image capture. In this study, the room had $200 \mathrm{~cm}$ length $\mathrm{x} 200 \mathrm{~cm}$ width, thus adequate to capture the images with comfort and effectiveness.

Prior to mark the landmarks, each participant wore a headband to fasten the hair and enable the best reading of the appliance. Face asepsis comprise 70\% alcohol applied with the aid of sterile gauze to clean the skin off debris, oil and make-up. According to the criteria stablished by Ferrario et al. and Sforza et al. the studied landmarks were [14,15]:

- Midline landmarks: N (nasion); Prn (pronasale); Sn (subnasale); Ls (labiale superius); Sto (stomion); Li (labiale inferius); Gn (Gnation).

- Paired landmarks (right and left): Enr e Enl (endocanthion); Zyr e Zyl (zygion); Alr and All (alare); Chr e Chl (cheilion).

Both the points Stomion (Sto) and Cheilion (Ch) were registered on the software. The landmarks were marked with the aid of liquid eyeliner (O Boticário ${ }^{\circledR}$, Brazil).

The participant was correctly seated and instructed to stay in a relaxed position to avoid soft tissue changes due to muscle tension. Instants before the image capture, the participant was instructed not to blink the eyes. The Vectra M3 device captured three photographs at once and made the 3D image of the face of each participant without physical contact between the device and the participant's face. Then, the quality of the image was checked. Next, a second image was captured to allow the mean value of the measurements by the software. Only after assuring the quality of the two images, the 
landmarks were removed. The participant's skin was cleaned with facial cleaning wipe.

\section{Studied measurements and indexes}

Linear distances - Face: face width (Zyr$\mathrm{Zyl}$ ), face morphology height (N-Gn), upper face height (N-Sto), lower face height (Sn-Gn). Nose: height (N-Sn), width (Alr-All), nose tip protrusion (Sn-Prn). Lips: right-left width of lip corners (Enr-Enl), mouth width (Chr-Chl), upper lip height (Sn-Sto), upper lip vermillion height (Ls-Sto), height of the upper lip skin portion (Sn-Ls), lower lip vermillion height (Sto-Li).

Indexes of face proportion - Face: Morphological facial index: face morphology height (N-Gn)/ face width (Zyr-Zyl) x 100. Upper face index: upper face height (N-Sto)/ face width (Zyr-Zyl) x 100. Lower face index: lower face height (Sn-Gn)/ face morphology height (N-Gn) x 100. Nose: Nasal Index: nose width (Alr-All)/nose height (N-Sn) x 100. Nasal tip protrusion width index: nose tip protrusion (Sn-Prn)/ nose width (Alr-All) x 100. Lips: Upper lip width index: upper lip height (SnSto)/mouth width (Chr-Chl) x 100. Skin portion upper lip index: height of the upper lip skin portion (Sn-Ls)/ upper lip height (Sn-Sto) $\mathrm{x}$ 100. Upper vermilion height index: upper lip vermillion height (Ls-Sto)/lower lip vermillion height (Sto-Li) x 100 [9].

\section{Statistical analysis}

Firstly, we obtained the descriptive statistics with means, standard-deviation, minimum and maximum values. The intergroup variables were tested regarding normality through ShapiroWilk test and showed parametric distribution. Thus, the intergroup comparisons regarding gender and nationality was performed by oneway ANOVA, adopting the level of significance of $5 \%$.

\section{RESULTS}

Table 1 shows the mean and standard deviation values obtained for all measurements regarding to population and gender and the intergroup comparisons. No statistically significant differences occurred between groups, for both population and gender in the Nasal Index ( $\mathrm{p}=0.23)$. However, the Brazilian male measurements (48.8) for the Nasal Tip Protrusion Width Index were statistically significant greater $(\mathrm{p}=0.04)$ than that for Brazilian females (45.4); Peruvian males (43.3), and Peruvian females (41.4) (Figure 1A).

The nose height $(\mathrm{p}=0.002)$ and width $(p=0.001)$ measurements showed statistically significant lower values for the Brazilian females (mean values of 49.5 and 33.2, respectively). The nose tip protrusion was statistically different for the Brazilian males $(\mathrm{p}=0.003)$, with mean value of 18.5 (Figure 1B). No statistically significant differences occurred in the intercantal width for all groups $(\mathrm{p}=0.19)$.

The Mouth width values exhibited statistically significant differences $(\mathrm{p}=0.001)$ only for Brazilian females (49) after the comparison with the other groups: Brazilian males (53.4); Peruvian females (52); Peruvian males (56.1). The Upper Lip Height did not show statistically significant differences between groups $(\mathrm{p}=0.37)$ (Figure $2 \mathrm{~A})$.

The measurements of the Upper Lip Width Index and Upper Vermilion Height Index exhibited no statistically significant differences between groups $(\mathrm{p}=0.16$ and 0.86 , respectively). The Skin Portion Upper Lip Index was statistically different for Brazilian males $(\mathrm{p}=0.01)$ (Figure 2B). The other measurements of the lips did not exhibit statistically significant differences: Vermilion Height - Upper Lip (0.22), Skin Height - Upper Lip (0.2) and Vermilion Height - Lower Lip (0.2) (Figure 2C).

The Brazilian females (136.4) had statistically significant wider faces $(p=0.0006)$ than the other groups: Brazilian males (146.8); Peruvian females (135.6); Peruvian males (144.6). Also, the Brazilian females (111.5) had statistically significant greater values $(p=0.0001)$ of Height of Facial Morphology than 
Table 1 - Mean values and standard deviation of linear measurements and proportion indices on the face, lip and nose for Peruvians and Brazilians male/female and comparison between populations and sex of the evaluated parameters (ANOVA One Way, p > 0.05).

\begin{tabular}{|c|c|c|c|c|c|c|c|c|c|c|c|}
\hline Parameter & $\begin{array}{l}\text { Peruvians } \\
\text { male (PM) }\end{array}$ & $\begin{array}{l}\text { Peruvians } \\
\text { female (PF) }\end{array}$ & $\begin{array}{l}\text { Brazilians } \\
\text { male (BM) }\end{array}$ & $\begin{array}{l}\text { Brazilians } \\
\text { female (BF) }\end{array}$ & $\begin{array}{l}\text { PM } \\
\text { vs.PF }\end{array}$ & $\begin{array}{l}\text { PMvs. } \\
\text { BM }\end{array}$ & $\begin{array}{l}\text { PMvs. } \\
\text { BF }\end{array}$ & $\begin{array}{l}\text { PFvs. } \\
\text { BM }\end{array}$ & $\begin{array}{l}\text { PFvs. } \\
\text { BF }\end{array}$ & $\begin{array}{l}\text { BMvs. } \\
\text { BF }\end{array}$ & P-value \\
\hline \multicolumn{12}{|l|}{ Face } \\
\hline Face width (Zy-Zy) & $144.6(5.1)$ & $135.6(4)$ & $146.8(7)$ & $136.4(3.8)$ & ns & ns & $<0.01$ & ns & ns & $<0.01$ & $0.0006^{\star}$ \\
\hline $\begin{array}{l}\text { Height of facial } \\
\text { morphology } \\
\text { (N-Gn) }\end{array}$ & $123.6(3.3)$ & $118.7(5.1)$ & $120.3(4.9)$ & $111.5(5)$ & ns & ns & $<0.01$ & ns & $\ll 0.01$ & $<0.01$ & $\ll 0.0001^{*}$ \\
\hline $\begin{array}{l}\text { Height of upper face } \\
\text { (N-Sto) }\end{array}$ & $76.5(4.5)$ & $76.4(3.5)$ & $75.9(3.8)$ & $70.9(2.4)$ & ns & ns & $<0.05$ & ns & $\ll 0.01$ & ns & $0.002^{\star}$ \\
\hline $\begin{array}{l}\text { Height of lower face } \\
\text { (Sn-Gn) }\end{array}$ & $71.2(3.6)$ & $67.1(4.5)$ & $68.8(4.8)$ & $64.5(4.1)$ & ns & ns & ns & ns & ns & ns & 0.09 \\
\hline $\begin{array}{c}\text { Facial morphological } \\
\text { index }\end{array}$ & $85.6(4.1)$ & $76(2.5)$ & 82.1(4.8) & $81.7(3.9)$ & ns & ns & ns & ns & ns & ns & 0.23 \\
\hline Upper face index & $52.9(3.8)$ & $48.7(1.6)$ & $51.8(3.6)$ & $52(2.1)$ & ns & ns & ns & ns & ns & ns & 0.37 \\
\hline Lower face index & $57.5(2.2)$ & $56.5(2.3)$ & $57.1(3.1)$ & $57.7(1.7)$ & ns & ns & ns & ns & ns & ns & 0.66 \\
\hline \multicolumn{12}{|l|}{ Lip } \\
\hline Mouth width (Ch-Ch) & $56.1(2.9)$ & $52(3)$ & $53.4(5.5)$ & $49(2.2)$ & ns & ns & $<0.01$ & ns & ns & $<0.05$ & $0.001^{\star}$ \\
\hline $\begin{array}{l}\text { Height of upper lip } \\
\text { (Sn-Sto) }\end{array}$ & $22.7(2.8)$ & $21.9(2.4)$ & $26.3(2.4)$ & $22.1(1.8)$ & ns & ns & ns & ns & ns & ns & 0.37 \\
\hline $\begin{array}{l}\text { Vermilion height of the } \\
\text { upper lip (Ls-Sto) }\end{array}$ & $7.2(1.9)$ & $8.7(0.9)$ & $7.8(2.4)$ & $8.4(1.1)$ & ns & ns & ns & ns & ns & ns & 0.22 \\
\hline $\begin{array}{l}\text { Height of the skin of the } \\
\text { upper lip portion (Sn-Ls) }\end{array}$ & $16.8(2.5)$ & $14.4(2.7)$ & $17.3(2.7)$ & $14.7(1.4)$ & ns & ns & ns & ns & ns & ns & 0.2 \\
\hline $\begin{array}{l}\text { Height of lower lip } \\
\text { vermillion (Sto-Li) }\end{array}$ & $9.3(2.4)$ & $11.3(1.4)$ & $10.2(2.4)$ & $11.3(1.3)$ & ns & ns & ns & ns & ns & ns & 0.2 \\
\hline Upper lip width index & $40.6(6.1)$ & $42.2(4.2)$ & $44.5(5.4)$ & $45(2.8)$ & ns & ns & ns & ns & ns & ns & 0.16 \\
\hline $\begin{array}{l}\text { Skin portion upper lip } \\
\text { index }\end{array}$ & $74.2(6.6)$ & $65.5(6.2)$ & $73.3(8.9)$ & $66.9(4.2)$ & $<0.05$ & ns & ns & ns & ns & ns & $0.01^{\star}$ \\
\hline $\begin{array}{l}\text { Upper vermilion height } \\
\text { index }\end{array}$ & $77.9(1.3)$ & $77.7(1.2)$ & $81.9(3.5)$ & $74.4(9)$ & ns & ns & ns & ns & ns & ns & 0.86 \\
\hline \multicolumn{12}{|l|}{ Nose } \\
\hline Nose height(N-Sn) & $55.7(3.4)$ & $54.3(3.3)$ & $53.5(4.5)$ & $49.5(2.2)$ & ns & ns & $<0.01$ & ns & $<0.05$ & ns & $0.002^{*}$ \\
\hline Nose width (Al-Al) & $39.7(1.9)$ & $35.9(2.6)$ & $38.2(3.3)$ & $33.2(2.4)$ & $<0.05$ & ns & $<0.01$ & ns & ns & $<0.01$ & $0.0001^{\star}$ \\
\hline $\begin{array}{l}\text { Protrusion of the tip of } \\
\text { the nose (Sn-Prn) }\end{array}$ & $17.2(2)$ & $14.8(1.5)$ & $18.5(2.4)$ & $15(1.5)$ & ns & ns & ns & $<0.01$ & ns & $<0.01$ & $0.0003^{*}$ \\
\hline $\begin{array}{l}\text { Intercantal width } \\
\quad \text { (En-En) }\end{array}$ & $33(2.2)$ & $34.4(2.6)$ & $33.5(4.1)$ & $31.4(3.2)$ & ns & ns & ns & ns & ns & ns & 0.19 \\
\hline Nasal index & $71.4(5.3)$ & $66.4(6.8)$ & $72(1)$ & $67.3(6)$ & ns & ns & ns & ns & ns & ns & 0.23 \\
\hline $\begin{array}{l}\text { Nasal tip protrusion } \\
\text { width index }\end{array}$ & $43.3(4.3)$ & $41.4(5.2)$ & $48.8(7.7)$ & $45.4(5.5)$ & ns & ns & ns & ns & $<0.05$ & ns & $0.04^{\star}$ \\
\hline
\end{tabular}

Note: ns: no significance; $5 \%$ as the significance level. 
A.
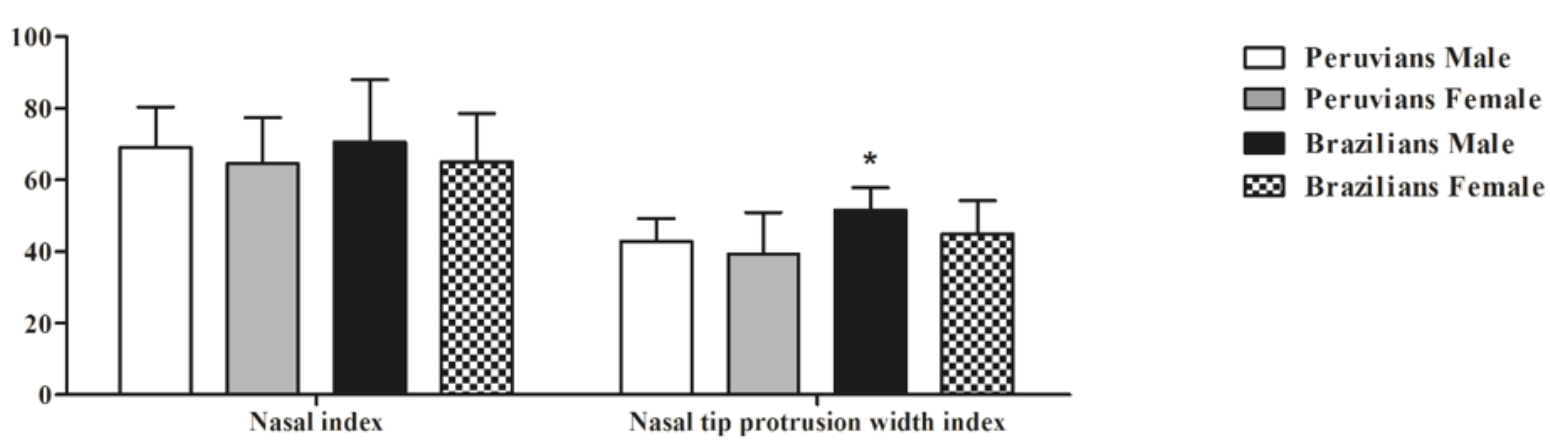

B.

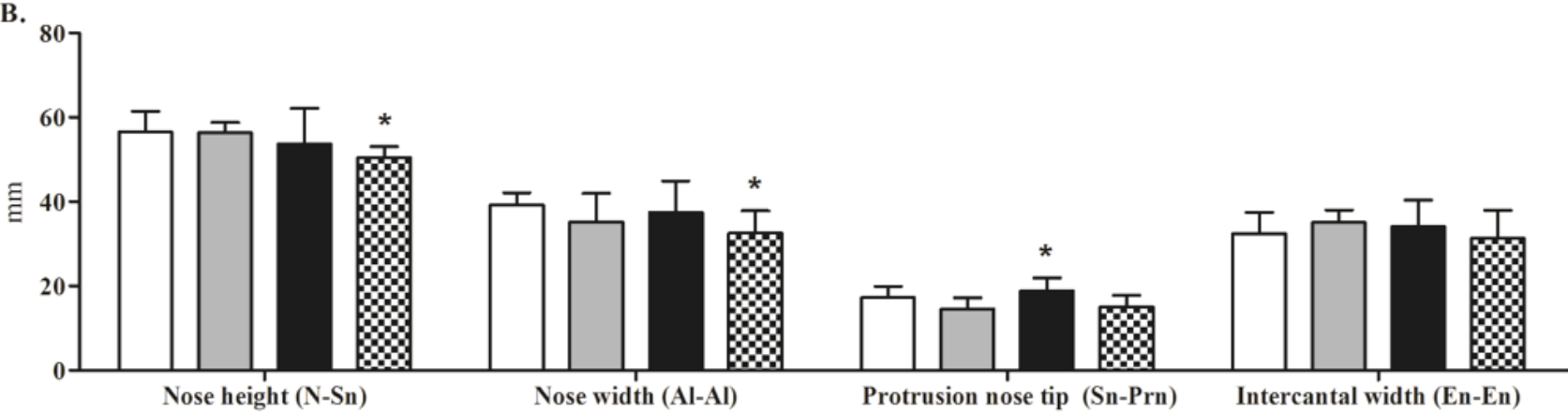

Figure 1 - A - Mean and standard deviation values of the Nasal Index and Nasal Tip Protrusion Width Index, for Brazilian and Peruvian males and females. B - Mean and standard deviation values of the Nose Heights (N-Sn), Nose width (Al-Al), Protrusion nose tip (Sn-Prn), and Intercantal width (En-En).

the other groups: Peruvian females (118.7); Peruvian males (123.6), and Brazilian males (120.3). (Figure 3A)

The Brazilian females (70.9) had statistically significant $(\mathrm{p}=0.002)$ lower Height of Upper Face than the other groups: Peruvian females (76.4); Peruvian males (76.5), and Brazilian males (75.9) (Figure 3B). The measurements of the Height of Lower Face did not show statistically significant differences for Brazilian females (64.5); Brazilian males (68.8); Peruvian females (67.1), and Peruvian males (71.2) (Figure 3B).

The intergroup comparison of the Facial Morphological Index (0.23), Upper Facial Index (0.37) and Lower Face Index (0.66) showed no statistically significant differences (Figure 3C). 
A.

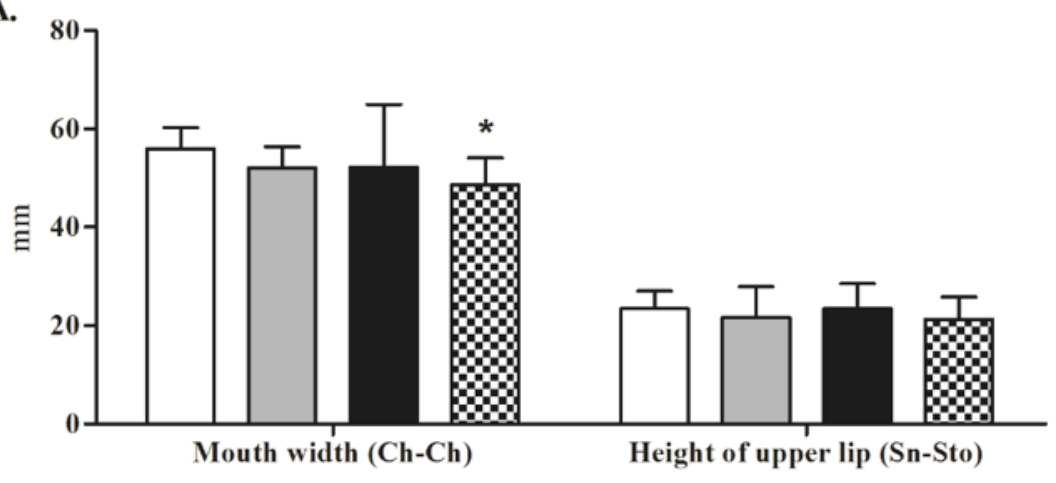

$\square$ Peruvians Male

$\square$ Peruvians Female

Brazilians Male

B Brazilians Female

B.

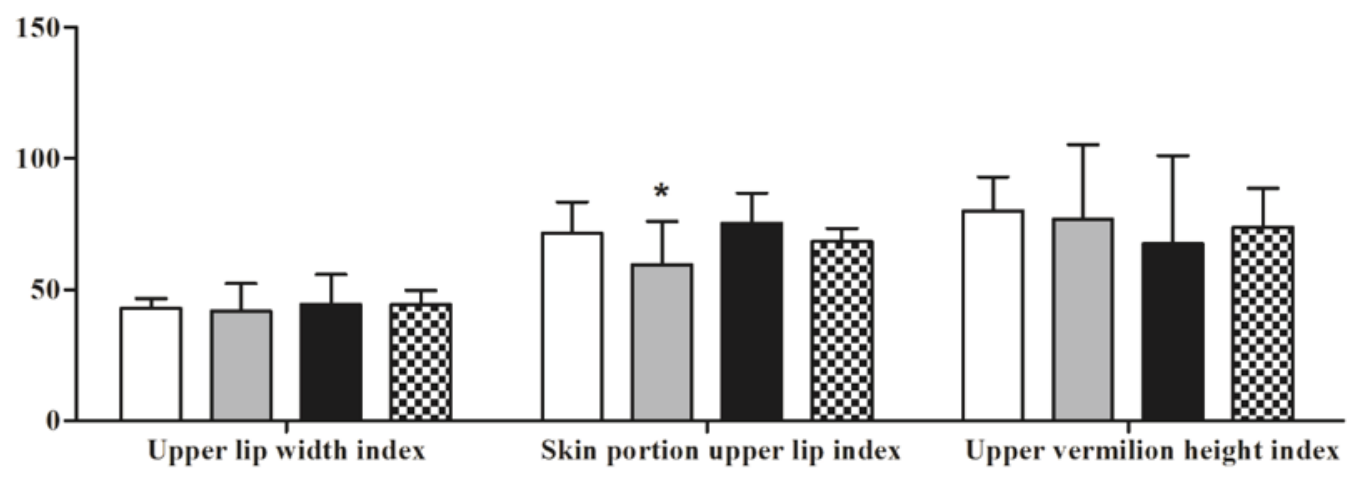

C.

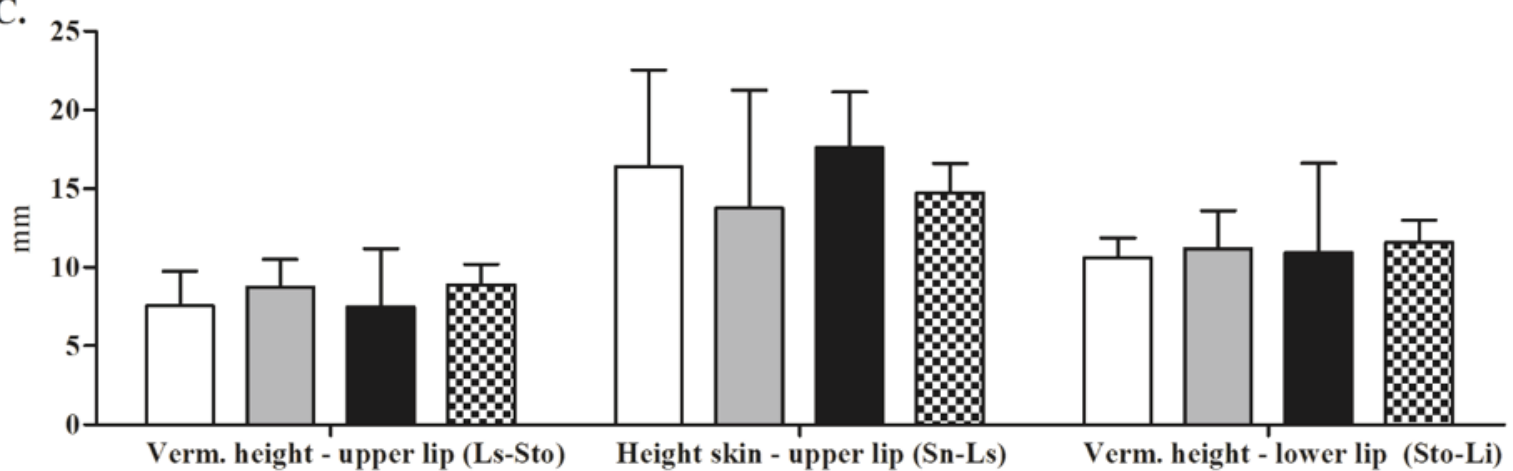

Figure 2 - A - Mean and standard deviation values of the Mouth width (Ch-Ch) and upper lip Height (Sn-Sto). B - Mean and standard deviation values of the Upper lip width index, upper lip Skin portion index and Upper vermilion height index. C - Mean and standard deviation values of the Vermilion height -upper lip (Ls-Sto), Height skin - upper lip (Sn - Ls) and Vermilion height - lower lip (Sto-Li). 
A.
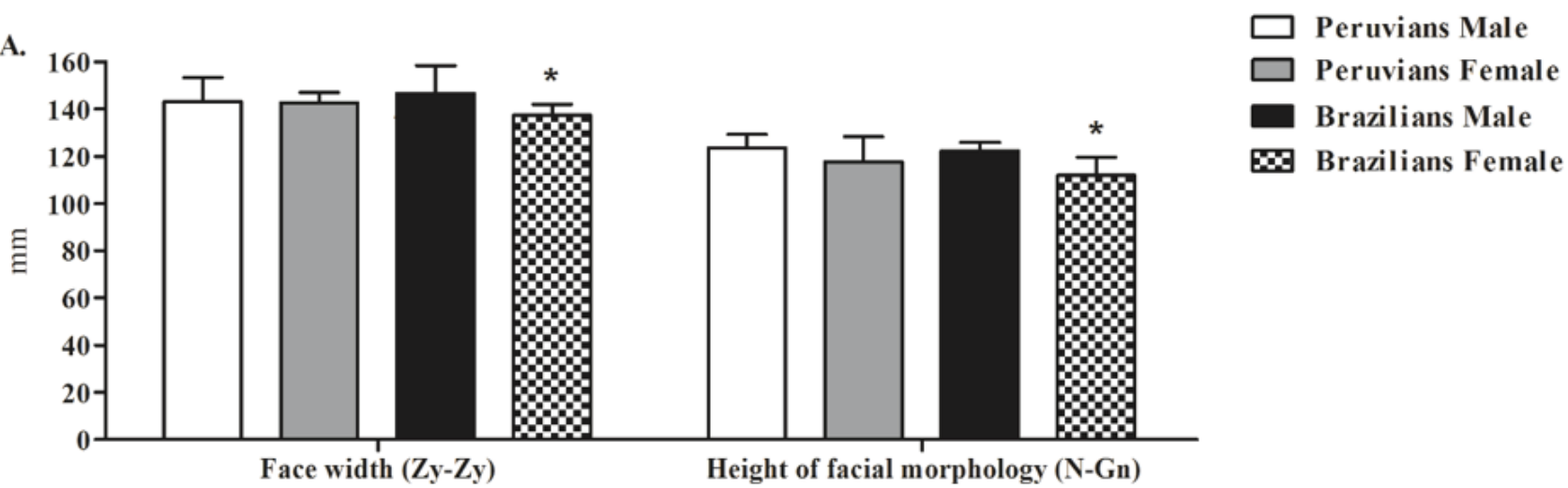

B.

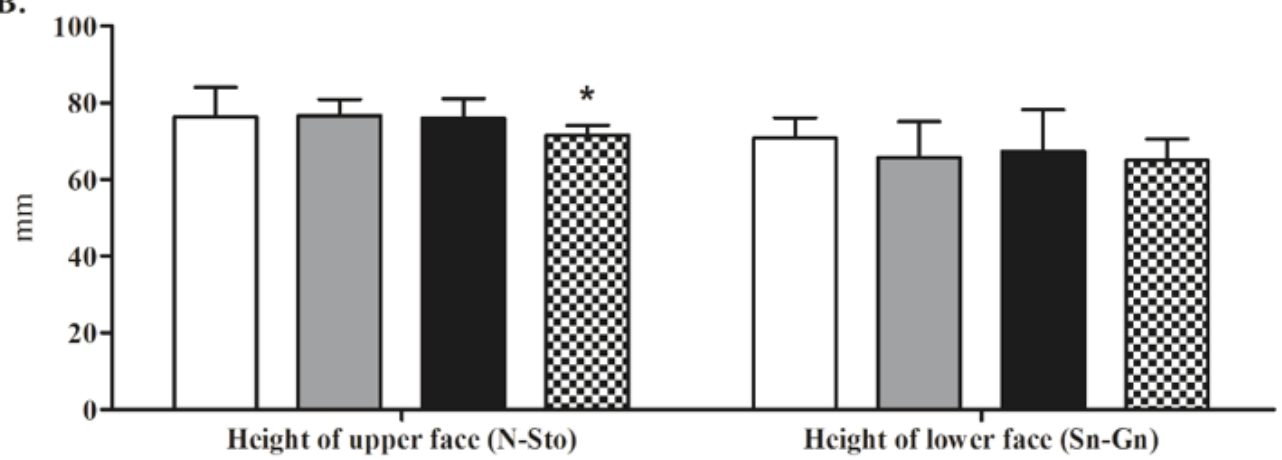

C.

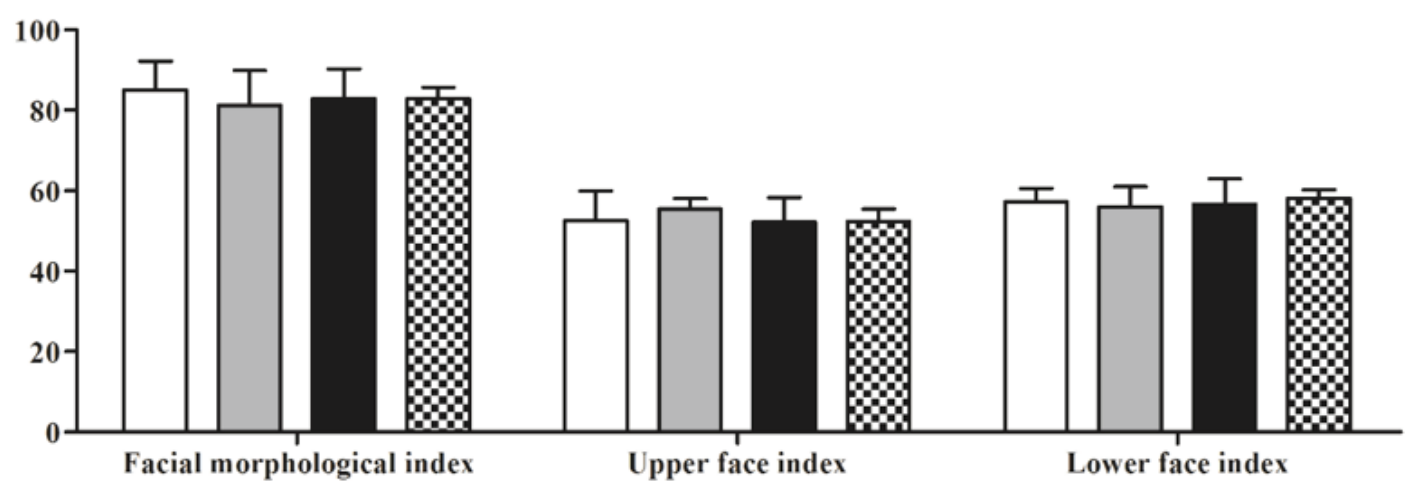

Figure 3 - Mean and standard deviation values of the Face width (Zy-Zy) and Height of facial morphology (N-Gn). B - Mean and standard deviation values of the Height of upper face (N-Sto) and Height of lower face (Sn-Gn). C - Mean and standard deviation values of the Facial morphological index, Upper facial index, and Lower face index.

\section{DISCUSSION}

The face structures are important in the individual's global perception of recognition. Small alterations in face structures greatly impact on the face harmony. Many studies analyzed the face structures alone, based in different populations [9,11,16-19]. The 3D stereophotogrammetry is the technique most used in current studies because it enables measuring variables with image depth, e.g.: volume, and linear/angular measurements [6,9,12,17-19].

Table 2 displays the studies used in this discussion and the measurements found by the authors and the comparison with those of this present study. The results of this study 
demonstrated that the Brazilian males and females had the greatest range of the nose measurements than did the Peruvians (Figure 1): the Brazilian females showed the narrowest and shortest noses, while the Brazilian males had the greatest measurements of nose tip protrusion than did the other groups. Other studies comparing genders already found that females, in general, exhibited thinner and shorter noses than males $[12,18,19]$.

Ngeow \& Aljunid observed a different result for nose height, with wider noses for females (mean of 54.1) than males (51.6) [10]. The rationale behind this difference may be the facial features of the Malaysians, but Othman et al. and Al-Khatib et al. found greater nose height for men $[18,19]$.

The Asian populations have wider noses than Caucasians, as shown by Dong et al. who evaluated the Chinese population and found nose width measurements for men of 37.5 and women of 42.9 [12]. Other studies conducted in Asian populations also indicated noses values wider than those of this present study, regardless of the gender $[10,18]$. Troncoso et al. evaluated a Chinese population and found results (35.2 for men and 37.3 for women) close to those obtained for the Brazilian and Peruvian population [16].

The nose tip protrusion was greater in both Brazilian and Peruvian males, as verified by the measurements Sn-Prn and Nasal Tip Protrusion Width Index (Figure 1-A and B). This range of the nose tip protrusion measurements between genders was also verified by other studies $[10,12,18,19]$. Othman et al. also evaluated the nose proportion indexes and found a result very similar to the present study: 67.7 for Nose Index and 43.3 for Nose Tip Protrusion; however, these authors did not verify the males and females alone [9].

The lip measurements showed small variations between Brazilians and Peruvians, in this study. Only the indexes mouth width and
Upper Lip Skin Portion exhibited differences. The genders did not reveal statistically significant differences, although women had decreased lip dimensions than men (Figure 2).

The study conducted by Othman et al. also verified the lip proportion indexes of Malaysians and the results comparison with those of this study revealed: similar Upper Lip Width Index; lower Skin Portion Upper Lip Index for Malaysians (63.5); and higher do Upper Vermillion Height Index for Malaysians (85.9) than for Brazilians and Peruvians, regardless of the gender [9].

Studies on the analysis of the face morphology of Asian populations showed mouth width values and upper lip vermillion height greater than those found by this present study $[10,13,18]$, while the studies on Black and White Americans observed mouth width values more similar to those of the Brazilians and Peruvians $[11,17]$. The vestibular shift of maxillary incisors and canines can affect the upper and lower vermilion areas of the lips [20], therefore the assessment of the upper anterior teeth shapes is important to the study of lips stereophotogrammetry, especially when comparing different ethnicities, which may present different trends of dental positioning [21]. In the present study, the volume and shape of the maxillary incisors and canines were not evaluated, which is a limitation that may influence the results obtained.

Sawyer et al. assessed the face measurements of a Caucasian population. The comparison of that study population with this study population revealed: similar mouth widths; shorter upper lip height and lower lip vermillion height for the Caucasians; shorter upper lip vermillion height for Brazilians and Peruvians. Notwithstanding, we highlight that this study population included a diversity of ethnic groups, including Caucasians [17].

The Brazilian females exhibited the thinnest face widths, shortest face morphology 
Table 2 - Linear measures and proportion indexes of nose, lips and face found in the present study and in other scientific articles, identified by authors, year of publication, population, age and gender. Data used in the discussion.

\begin{tabular}{|c|c|c|c|c|c|c|c|c|c|c|c|c|c|c|c|c|c|c|c|c|}
\hline Measurements & \multicolumn{3}{|c|}{$\begin{array}{l}\text { Present study } \\
\qquad(\mathrm{n}=41)\end{array}$} & \multicolumn{2}{|c|}{$\begin{array}{l}\text { Porter \& Olson, } \\
2001(n=108)\end{array}$} & \multicolumn{2}{|c|}{$\begin{array}{c}\text { Troncoso } \\
\text { et al., } \\
2008 \\
(n=180)\end{array}$} & \multicolumn{2}{|c|}{$\begin{array}{c}\text { Sawyer } \\
\text { et al., } \\
2009 \\
(n=70)\end{array}$} & \multicolumn{2}{|c|}{$\begin{array}{c}\text { Dong } \\
\text { et al., } \\
2009 \\
(n=289)\end{array}$} & \multicolumn{2}{|c|}{$\begin{array}{c}\text { Ngeow \& } \\
\text { Aljunid, } \\
2009 \\
(n=100)\end{array}$} & \multicolumn{2}{|c|}{$\begin{array}{c}\text { Al-Khatib } \\
\text { et al., } \\
2012 \\
(n=50)\end{array}$} & \multicolumn{2}{|c|}{$\begin{array}{l}\text { Yasas et } \\
\text { al.,2013 } \\
(n=103)\end{array}$} & $\begin{array}{l}\text { Othman } \\
\text { et al.,2014 } \\
(n=100)\end{array}$ & \multicolumn{2}{|c|}{$\begin{array}{c}\text { Othman } \\
\text { et al., 2016 } \\
(n=109)\end{array}$} \\
\hline Population & Brazilian & Perul & Ivian & $\begin{array}{l}\text { African } \\
(A A) X N \\
\text { can Caur }\end{array}$ & $\begin{array}{l}\text { Imerican } \\
\text { th Ameri- } \\
\text { sian (NAC) }\end{array}$ & Chile & ean & Cauc & asian & Chin & nese & $\mathrm{Mal}$ & & $\begin{array}{r}\text { Asial } \\
\mathrm{Ma}\end{array}$ & $\begin{array}{l}\text { nand } \\
\text { alay }\end{array}$ & Chine & & $\begin{array}{l}\text { Malay } \\
\text { (Health } \\
\text { Sample) }\end{array}$ & Mal & \\
\hline Age & $18-40$ & \multicolumn{2}{|c|}{$18-40$} & \multicolumn{2}{|c|}{$18-30$} & \multicolumn{2}{|c|}{$18-30$} & \multicolumn{2}{|c|}{$21-49$} & \multicolumn{2}{|c|}{$20-31$} & \multicolumn{2}{|c|}{$18-25$} & \multicolumn{2}{|c|}{$18-36$} & \multicolumn{2}{|c|}{ 18-35 } & $18-25$ & \multicolumn{2}{|c|}{$20-30$} \\
\hline Sex & $M$ & $F$ & $M$ & F-NAC & $F-A A$ & $F$ & $M$ & $F$ & M & $F$ & $M$ & $F$ & $M$ & $F$ & $M$ & $F$ & $M$ & $F / M$ & $F$ & $M$ \\
\hline \multicolumn{21}{|l|}{ Nose } \\
\hline Nose Height & $\begin{array}{ll}49.5 & 53.5 \\
(2.2) & (4.5)\end{array}$ & $\begin{array}{l}54.3 \\
(3.3)\end{array}$ & $\begin{array}{l}55.7 \\
(3.4)\end{array}$ & 50.6 & $\begin{array}{l}48.0 \\
(0.4)\end{array}$ & - & & - & - & 52.4 & 54.3 & $\begin{array}{l}54.1 \\
(2.9)\end{array}$ & $\begin{array}{l}51.6 \\
(3.5)\end{array}$ & $\begin{array}{l}51.2 \\
(3.5)\end{array}$ & $\begin{array}{l}56.0 \\
(4.6)\end{array}$ & - & - & - & $\begin{array}{l}49.2 \\
(3.5)\end{array}$ & $\begin{array}{l}54.1 \\
(3.6)\end{array}$ \\
\hline Nose Width & $\begin{array}{ll}33.2 & 38.2 \\
(2.4) & (3.3)\end{array}$ & $\begin{array}{l}35.9 \\
(2.6)\end{array}$ & $\begin{array}{l}39.7 \\
(1.9)\end{array}$ & 31.4 & $\begin{array}{l}38.0 \\
(0.3)\end{array}$ & $\begin{array}{l}35.2 \\
(5.5)\end{array}$ & $\begin{array}{l}37.3 \\
(5.0)\end{array}$ & & & 37.5 & 42.9 & $\begin{array}{l}37.3 \\
(2.6)\end{array}$ & $\begin{array}{l}41.0 \\
(2.0)\end{array}$ & $\begin{array}{l}37.4 \\
(2.3)\end{array}$ & $\begin{array}{l}40.3 \\
(2.2)\end{array}$ & - & - & - & $\begin{array}{l}36.7 \\
(2.4)\end{array}$ & $\begin{array}{l}39.6 \\
(2.2)\end{array}$ \\
\hline $\begin{array}{l}\text { Protrusion Nose } \\
\text { Tip }\end{array}$ & $\begin{array}{cc}15 & 18.5 \\
(1.5) & (2.4)\end{array}$ & $\begin{array}{l}14.8 \\
(1.5)\end{array}$ & $\begin{array}{l}17.2 \\
(2)\end{array}$ & - & - & - & - & - & - & 19.4 & 20.5 & $\begin{array}{l}17.5 \\
(1.5)\end{array}$ & $\begin{array}{r}18.1 \\
(1.6)\end{array}$ & $\begin{array}{l}17.7 \\
(2.3)\end{array}$ & $\begin{array}{l}18.4 \\
(3.2)\end{array}$ & - & - & - & $\begin{array}{l}16.1 \\
(1.7)\end{array}$ & $\begin{array}{l}17.3 \\
(1.8)\end{array}$ \\
\hline Intercantal Width & $\begin{array}{ll}31.4 & 33.5 \\
(3.2) & (4.1)\end{array}$ & $\begin{array}{l}34.4 \\
(2.6)\end{array}$ & $\begin{array}{c}33 \\
(2.2)\end{array}$ & 31.8 & $\begin{array}{l}31.4 \\
(0.3)\end{array}$ & $\begin{array}{l}30.3 \\
(4.4)\end{array}$ & $\begin{array}{l}30.3 \\
(5.0)\end{array}$ & & & 35.3 & 36.9 & $\begin{array}{l}32.5 \\
(1.7)\end{array}$ & $\begin{array}{l}33.9 \\
(1.9)\end{array}$ & - & - & - & - & $32.7(2.5)$ & $\begin{array}{l}35.0 \\
(2.5)\end{array}$ & $\begin{array}{l}35.7 \\
(2.8)\end{array}$ \\
\hline Nasal index & $\begin{array}{cc}67.3 & 72 \\
(6) & (1)\end{array}$ & $\begin{array}{l}66.4 \\
(6.8)\end{array}$ & $\begin{array}{l}71.4 \\
(5.3)\end{array}$ & - & - & - & - & - & - & - & - & - & - & - & - & - & - & $67.7(7.2)$ & & - \\
\hline $\begin{array}{l}\text { Nasal Tip Protru- } \\
\text { sion Width Index }\end{array}$ & $\begin{array}{ll}45.4 & 48.8 \\
(5.5) & (7.7)\end{array}$ & $\begin{array}{l}41.4 \\
(5.2)\end{array}$ & $\begin{array}{l}43.3 \\
(4.3)\end{array}$ & - & - & - & - & - & - & - & - & - & - & - & - & - & - & $43.4(4.6)$ & - & - \\
\hline \multicolumn{21}{|l|}{ Lips } \\
\hline Mouth Width & $\begin{array}{cc}49 & 53.4 \\
(2.2) & (5.5)\end{array}$ & $\begin{array}{l}52 \\
(3)\end{array}$ & $\begin{array}{l}56.1 \\
(2.9)\end{array}$ & 50.2 & $\begin{array}{l}51.6 \\
(0.3)\end{array}$ & - & - & 48.1 & 52.2 & - & - & $\begin{array}{l}47.1 \\
(3.5)\end{array}$ & $\begin{array}{l}48.8 \\
(3.5)\end{array}$ & $\begin{array}{l}49.4 \\
(3.9)\end{array}$ & $\begin{array}{l}51.3 \\
(3.4)\end{array}$ & $\begin{array}{l}45.2 \\
(3.5)\end{array}$ & $\begin{array}{l}49.7 \\
(3.7)\end{array}$ & - & $\begin{array}{l}48.0 \\
(2.6)\end{array}$ & $\begin{array}{l}50.8 \\
(3.7)\end{array}$ \\
\hline Height Upper Lip & $\begin{array}{ll}22.1 & 26.3 \\
(1.8) & (2.4)\end{array}$ & $\begin{array}{l}21.9 \\
(2.4)\end{array}$ & $\begin{array}{l}22.7 \\
(2.8)\end{array}$ & - & - & - & - & 19.2 & 21.3 & - & - & $\begin{array}{l}21.1 \\
(1.9)\end{array}$ & $\begin{array}{l}22.7 \\
(2.0)\end{array}$ & $\begin{array}{l}20.9 \\
(1.9)\end{array}$ & $\begin{array}{l}23.4 \\
(2.4)\end{array}$ & $\begin{array}{l}21.5 \\
(2.0)\end{array}$ & $\begin{array}{l}23.4 \\
(2.7)\end{array}$ & - & $\begin{array}{l}21.3 \\
(1.8)\end{array}$ & $\begin{array}{l}22.8 \\
(2.1)\end{array}$ \\
\hline $\begin{array}{l}\text { Upper Verm. } \\
\text { Height }\end{array}$ & $\begin{array}{cc}8.4 & 7.8 \\
(1.1) & (2.4)\end{array}$ & $\begin{array}{l}8.7 \\
(0.9)\end{array}$ & $\begin{array}{c}7.2 \\
(1.9)\end{array}$ & - & - & - & - & 9.0 & 10.1 & - & - & $\begin{array}{c}9.1 \\
(1.0)\end{array}$ & $\begin{array}{l}9.8 \\
(1.1)\end{array}$ & $\begin{array}{c}9.2 \\
(1.6)\end{array}$ & $\begin{array}{l}10.3 \\
(1.9)\end{array}$ & $\begin{array}{c}9.1 \\
(1.7)\end{array}$ & $\begin{array}{l}10.2 \\
(1.9)\end{array}$ & - & $\begin{array}{l}10.3 \\
(1.6)\end{array}$ & $\begin{array}{l}10.3 \\
(1.9)\end{array}$ \\
\hline Upper skin Height & $\begin{array}{ll}14.7 & 17.3 \\
(1.4) & (2.7)\end{array}$ & $\begin{array}{l}14.4 \\
(2.7)\end{array}$ & $\begin{array}{l}16.8 \\
(2.5)\end{array}$ & - & - & - & - & & & - & - & & & & & & & - & & \\
\hline $\begin{array}{l}\text { Lower Verm. } \\
\text { Height }\end{array}$ & $\begin{array}{ll}11.3 & 10.2 \\
(1.3) & (2.4)\end{array}$ & $\begin{array}{l}11.3 \\
(1.4)\end{array}$ & $\begin{array}{l}9.3 \\
(2.4)\end{array}$ & - & - & - & - & 8.4 & 10.8 & - & - & $\begin{array}{l}11.0 \\
(1.2)\end{array}$ & $\begin{array}{l}12.0 \\
(1.6)\end{array}$ & $\begin{array}{l}10.0 \\
(2.1)\end{array}$ & $\begin{array}{l}9.9 \\
(2.3)\end{array}$ & $\begin{array}{l}9.8 \\
(1.6)\end{array}$ & $\begin{array}{l}11.0 \\
(1.6)\end{array}$ & - & $\begin{array}{l}9.82 \\
(1.7)\end{array}$ & $\begin{array}{l}10.2 \\
(2.0)\end{array}$ \\
\hline $\begin{array}{l}\text { Upper Lip Width } \\
\text { Index }\end{array}$ & $\begin{array}{cc}45 & 44.5 \\
(2.8) & (5.4)\end{array}$ & $\begin{array}{l}42.2 \\
(4.2)\end{array}$ & $\begin{array}{l}40.6 \\
(6.1)\end{array}$ & - & - & - & - & - & - & - & - & - & - & - & - & - & - & $43.6(3.9)$ & - & - \\
\hline $\begin{array}{l}\text { Skin Portion Up- } \\
\text { per Lip Index }\end{array}$ & $\begin{array}{ll}66.9 & 73.3 \\
(4.2) & (8.9)\end{array}$ & $\begin{array}{l}65.5 \\
(6.2)\end{array}$ & $\begin{array}{l}74.2 \\
(6.6)\end{array}$ & - & - & - & - & - & - & - & - & - & - & - & - & - & - & $63.5(7.1)$ & - & - \\
\hline $\begin{array}{l}\text { Upper Verm. } \\
\text { Height Index }\end{array}$ & $\begin{array}{cc}74.4 & 81.9 \\
(9) & (3.5)\end{array}$ & $\begin{array}{l}77.7 \\
(1.2)\end{array}$ & $\begin{array}{l}77.9 \\
(1.3)\end{array}$ & - & - & - & - & - & - & - & - & - & - & - & - & - & - & $85.9(11.7)$ & - & - \\
\hline
\end{tabular}




\begin{tabular}{|c|c|c|c|c|c|c|c|c|c|c|c|c|c|c|c|c|c|c|c|c|}
\hline Measurements & $\begin{array}{l}\text { Presen } \\
\qquad(n=\end{array}$ & $\begin{array}{l}\text { t stud } \\
\text { =41) }\end{array}$ & & $\begin{array}{r}\text { PorteI } \\
2001\end{array}$ & $\begin{array}{l}\text { Olson, } \\
=108)\end{array}$ & $\begin{array}{r}\text { Tron } \\
\text { et } \\
20 \\
(n=\end{array}$ & & $\begin{array}{r}\text { Sav } \\
\text { et } \\
20 \\
(n=\end{array}$ & & $\begin{array}{r}\text { Do } \\
\text { et } \\
20 \\
(n=2\end{array}$ & $\begin{array}{l}\text { gg } \\
\text { l., } \\
\text { 89) }\end{array}$ & $\begin{array}{r}\text { Ngeo } \\
\text { AljuI } \\
200 \\
(n=1\end{array}$ & $\begin{array}{l}\text { ow \& } \\
\text { Inid, } \\
09 \\
\text { 100) }\end{array}$ & $\begin{array}{l}\text { AI-KI } \\
\text { et } \\
20 \\
(n=\end{array}$ & & & $\begin{array}{l}\text { set } \\
013 \\
03)\end{array}$ & $\begin{array}{l}\text { Othman } \\
\text { et al., 2014 } \\
(n=100)\end{array}$ & \multicolumn{2}{|c|}{$\begin{array}{c}\text { Othman } \\
\text { et al., 2016 } \\
(n=109)\end{array}$} \\
\hline Population & \multicolumn{3}{|c|}{ Brazilian Peruvian } & \multicolumn{2}{|c|}{$\begin{array}{l}\text { African American } \\
\text { (AA) X North Ameri- } \\
\text { can Caucasian (NAC) }\end{array}$} & \multicolumn{2}{|c|}{ Chilean } & \multicolumn{2}{|c|}{ Caucasian } & \multicolumn{2}{|c|}{ Chinese } & \multicolumn{2}{|c|}{ Malay } & \multicolumn{2}{|c|}{$\begin{array}{c}\text { Asian and } \\
\text { Malay }\end{array}$} & \multicolumn{2}{|c|}{ Chinese } & $\begin{array}{l}\text { Malay } \\
\text { (Normal } \\
\text { Sample) }\end{array}$ & \multicolumn{2}{|c|}{ Malay } \\
\hline Age & $18-40$ & \multicolumn{2}{|c|}{$18-40$} & \multicolumn{2}{|c|}{$18-30$} & \multicolumn{2}{|c|}{$18-30$} & \multicolumn{2}{|c|}{$21-49$} & \multicolumn{2}{|c|}{$20-31$} & \multicolumn{2}{|c|}{$18-25$} & \multicolumn{2}{|c|}{$18-36$} & \multicolumn{2}{|c|}{$18-35$} & $18-25$ & \multicolumn{2}{|c|}{$20-30$} \\
\hline Sex & $F \quad M$ & $F$ & $M$ & $F-N A C$ & $F-A A$ & $F$ & $M$ & $F$ & $M$ & $F$ & $M$ & $F$ & $M$ & $F$ & $M$ & $F$ & $M$ & $F / M$ & $F$ & $M$ \\
\hline \multicolumn{21}{|l|}{ Face } \\
\hline Face Width & $\begin{array}{cc}136 & 146 \\
(3.8) & (7)\end{array}$ & $\begin{array}{l}135 \\
(4)\end{array}$ & $\begin{array}{l}144 \\
(5.1)\end{array}$ & 130 & $\begin{array}{l}135 \\
(0.5)\end{array}$ & - & - & - & - & - & - & $\begin{array}{c}118 \\
(5.8)\end{array}$ & $\begin{array}{c}119 \\
(6.2)\end{array}$ & - & - & - & - & - & $\begin{array}{l}111.5 \quad 1 \\
(5.2) \quad(5\end{array}$ & $\begin{array}{l}119 . \\
(5.7)\end{array}$ \\
\hline $\begin{array}{l}\text { HeightFacial } \\
\text { Morphological }\end{array}$ & $\begin{array}{ll}111 & 120 \\
(5) & (4.9)\end{array}$ & $\begin{array}{l}118 \\
(5.1)\end{array}$ & $\begin{array}{l}123 \\
(3.3)\end{array}$ & - & - & - & - & - & - & - & - & - & - & - & - & - & - & - & - & - \\
\hline $\begin{array}{l}\text { HeightUpper } \\
\text { Face }\end{array}$ & $\begin{array}{ll}70.9 & 75.9 \\
(2.4) & (3.8)\end{array}$ & $\begin{array}{l}76.4 \\
(3.5)\end{array}$ & $\begin{array}{l}76.5 \\
(4.5)\end{array}$ & - & - & - & - & - & - & - & - & - & - & - & - & - & - & - & - & - \\
\hline $\begin{array}{l}\text { Height Lower } \\
\text { Face }\end{array}$ & $\begin{array}{ll}64.5 & 68.8 \\
(4.1) & (4.8)\end{array}$ & $\begin{array}{l}67.1 \\
(4.5)\end{array}$ & $\begin{array}{l}71.2 \\
(3.6)\end{array}$ & - & - & - & - & - & - & - & - & - & - & - & - & - & - & - & $\begin{array}{l}64.736 \\
(4.2)(4\end{array}$ & $\begin{array}{l}68.6 \\
(4.6)\end{array}$ \\
\hline $\begin{array}{l}\text { Facial Morpho- } \\
\text { logical Index }\end{array}$ & $\begin{array}{ll}81.7 & 82.1 \\
(3.9) & (4.8)\end{array}$ & $\begin{array}{c}76 \\
(2.5)\end{array}$ & $\begin{array}{l}85.6 \\
(4.1)\end{array}$ & - & - & - & - & - & - & - & - & - & - & - & - & - & - & $92.2(9.4)$ & - & - \\
\hline Upper Face Index & $\begin{array}{cc}52 & 51.8 \\
(2.1) & (3.6)\end{array}$ & $\begin{array}{l}48.7 \\
(1.6)\end{array}$ & $\begin{array}{l}52.9 \\
(3.8)\end{array}$ & - & - & - & - & - & - & - & - & - & - & - & - & - & - & $61.3(6.9)$ & - & - \\
\hline Lower Face Index & $\begin{array}{ll}57.7 & 57.1 \\
(1.7) & (3.1)\end{array}$ & $\begin{array}{l}56.5 \\
(2.3)\end{array}$ & $\begin{array}{l}57.5 \\
(2.2)\end{array}$ & - & - & - & - & - & - & - & - & - & - & - & - & - & - & $53.5(2.7)$ & - & - \\
\hline
\end{tabular}

and shortest upper face height. The Brazilian and Peruvian males and females had face width values higher than those of Malaysians [10,19], although the upper face height did not show great variation.

The Face Morphology Index determines the relation between the face width and height, that is, the higher the index value, the longest is the face. In this study, the Peruvian females showed the smallest mean value of Face Morphology Index, indicating that proportionally, they had the shortest face. In the study of Othman et al. with Malaysians, the value found for Face Morphology Index was 92.2, for males and females, considerably higher than that of the Brazilians and Peruvians [9].

Similarly, the Upper and Lower Face Index revealed numerically the proportion between the height and width of the face thirds. By comparing this study results with those of Othman et al., the Brazilians and Peruvians had greater Lower Face Index and smaller Upper Face Index than those of Malaysians. That is, both the Brazilians and the Peruvians had the lower third greater than the upper third of the face, while the Malaysians showed an inversely proportion relation [9].

The golden ratio is a measure of facial proportion considered more attractive and related to the beauty. Several studies have shown that beautiful faces have facial measurements close to the golden ratio, which value of "Phi" is approximately 1.6 [22-25]. Recent studies analyzed the ratio of the bizygomatic width to the total facial height (facial index) of different samples and categorize into different facial 
shapes based on the relationship with the golden ratio $(1.6-1.699=$ normal, $<1.6=$ short and $>1.699=$ long) $[22,23]$. In the present study, it was calculated the facial index for the upper, middle and lower portions of the face, and the results showed no statistically significant differences between Brazilians and Peruvians.

The results of this present study demonstrated that the Brazilian females had the greatest differences. The rationale behind this fact would be either the dimorphism or the larger Caucasian heritage of the Brazilian females than that of Peruvian females. A prior study conducted on the Brazilian population verified that Caucasians generally had smaller face proportions than did the Blacks and Asians [8].

\section{CONCLUSION}

The proportion indexes of the face, lips, and nose did not reveal great differences between Brazilians and Peruvians and between genders. The main differences were in the width and height of the face and nose; upper face height; mouth width; and nose tip protrusion. Generally, the Brazilian females had the smallest face measurements than the Peruvians. These differences may be related to the sexual dimorphism and the Caucasian heritage.

\section{REFERENCES}

1. Rodríguez AB, Patiño JCO, Cardona JAT. Determinación del biotipo facial basado en características fenotípicas através del modelo de ecuaciones estructurales: estudio sobre tres etnias. Rev Fac Odontol Univ Antioq. 2013;25(1):132-46.

2. Prates LS, Gois M, Berwig LC, Blanco-Dutra AP, Busanello-Stella AR, Silva AM. Avaliação clínica e eletromiográfica da mastigação nos diferentes padrões de crescimento facial. Rev CEFAC. 2016;18(1):104-11.

3. Weinberg SM, Naidoo S, Govier DP, Martin RA, Kane AA, Marazita $M L$. Anthropometric precision and accuracy of digital threedimensional photogrammetry: comparing the Genex and 3dMD imaging systems with one another and with direct anthropometry. J Craniofac Surg. 2006 May;17(3):477-83.

4. De Menezes M, Rosati R, Ferrario VF, Sforza C. Accuracy and reproducibility of a 3-dimensional stereophotogrammetric imaging system. J Oral Maxillofac Surg. 2010 Sep;68(9):2129-35. doi: 10.1016/j.joms.2009.09.036.
5. Plooij JM, Maal TJJ, Haers P. Digital three-dimensional image fusion processes for planning and evaluating orthodontics and orthognathic surgery. A systematic review. Int J Oral Maxillofac Surg. 2011 Apr;40(4):341-52. doi: 10.1016/j.ijom.2010.10.013. Epub 2010 Nov 20.

6. Wong JY, Oh AK, Ohta E, Hunt AT, Rogers GF, Mulliken JB, et al. Validity and reliability of craniofacial anthropometric measurement of 3D digital photogrammetric images. Cleft Palate Craniofac J. 2008 May;45(3):232-9. doi: 10.1597/06-175.

7. Da Silva AMBR, Magri LV, Junqueira Júnior AA, Da Silva MAMR. 3D stereophotogrammetry facial analysis of Angle I subjects: gender comparison. Rev Odontol UNESP. 2015;44(3):137-42.

8. Da Silva AM, Magri LV, Andrade LM, da Silva MA. Three-dimensional analysis of facial morphology in Brazilian population with Caucasian, Asian, and Black ethnicity. J Oral Res Rev. 2017;9:1-7.

9. Othman SA, Ahmad R, Asi SM, Ismail NH, Rahman ZAA. Threedimensional quantitative evaluation of facial morphology in adults with unilateral cleft lip and palate, and patients without clefts. Br J Oral Maxillofac Surg. 2014 Mar;52(3):208-13. doi: 10.1016/j. bjoms.2013.11.008. Epub 2013 Dec 15.

10. Ngeow WC, Aljunid ST. Craniofacial anthropometric norms of Malays. Singapore Med J. 2009 May;50(5):525-8.

11. Porter JP, Olson KL. Anthropometric Facial Analysis of the African American Woman. Arch Facial Plast Surg. 2001 Jul-Sep;3(3):191-7.

12. Dong Y, Zhao Y, Bai S, Wu G, Wang B. Three-dimensional anthropometric analysis of the Chinese nose. J Plast Reconstr Aesthet Surg. 2010 Nov;63(11):1832-9. doi: 10.1016/j. bjps.2009.11.035. Epub 2010 Jan 13.

13. Jayaratne BDS, Deutsch CK, Zwahlen RA. A 3D Anthropometric Analysis of the Orolabial Region in Chinese Young Adults. $\mathrm{Br}$ J Oral Maxillofac Surg. 2013 Dec;51(8):908-12. doi: 10.1016/j. bjoms.2013.09.002. Epub 2013 0ct 3.

14. Ferrario VF, Sforza C, Poggio CE, Cova M, Tartaglia G. Preliminary evaluation of na electromagnetic three-dimensional digitizer in facial anthropometry. Cleft Palate Craniofac J. 1998 Jan;35(1):9-15.

15. Sforza C, Elamin F, Tommasi DG, Dolci C, Ferrario VF. Morphometry of the soft tissues of the orbital region in Northern Sudanese persons. Forensic Sci Int. 2013 May 10;228(1-3):180.e1-11. doi: 10.1016/j.forsciint.2013.02.003. Epub 2013 Feb 28.

16. Troncoso Pazos JA, Suazo Galdames IV, Cantin Lopez M, Zavando Matamata DA. Sexual dimorphism in the nose morphotype in adult Chilean. Int J Morphol. 2008;26(3):537-42.

17. Sawyer AR, See M, Nduka C. 3D Stereophotogrammetry Quantitative Lip Analysis. Aesthetic Plast Surg. 2009 Jul;33(4):497504. doi: 10.1007/s00266-008-9191-1. Epub 2008 Jun 27.

18. Al-Khatib AR, Rajion ZA, Masudi SM, Hassan R, Anderson PJ, Townsend GC. Stereophotogrammetric Analysis of Nasolabial Morphology Among Asian Malays: Influence of Age and Sex. Cleft Palate Craniofac J. 2012 Jul;49(4):463-71. doi: 10.1597/11-151. Epub 2012 Jan 11.

19. Othman SA, Majawit LP, Hassan WNW, Wey MC, Razi RM. Anthropometric Study of Three-Dimensional Facial Morphology in Malay Adults. PLoS One. 2016 0ct 5;11(10):e0164180. doi: 10.1371/ journal.pone.0164180. eCollection 2016.

20. Rosati R, De Menezes M, da Silva AM, Rossetti A, Lanza Attisano GC, Sforza C. Stereophotogrammetric evaluation of tooth-induced 
labial protrusion. J Prosthodont. 2014 Jul;23(5):347-52. doi: 10.1111/ jopr.12135. Epub 2014 Feb 4.

21. Brock RA 2nd, Taylor RW, Buschang PH, Behrents RG. Ethnic differences in upper lip response to incisor retraction. Am J Orthod Dentofacial Orthop. 2005 Jun;127(6):683-91; quiz 755.

22. Alam MK, Mohd Noor NF, Basri R, Yew TF, Wen TH. Multiracial Facial Golden Ratio and Evaluation of Facial Appearance. PLoS One. 2015 Nov 12;10(11):e0142914. doi: 10.1371/journal.pone.0142914. eCollection 2015.

23. Packiriswamy V, Kumar P, Rao M. Identification of facial shape by applying golden ratio to the facial measurements: an interracial study in malaysian population. N Am J Med Sci. 2012 Dec;4(12):624-9. doi: 10.4103/1947-2714.104312.

24. Pancherz H, Knapp V, Erbe C, Heiss AM. Divine proportions in attractive and nonattractive faces. World J Orthod. 2010 Spring;11(1):27-36.

25. Kiekens RM, Kuijpers-Jagtman AM, van 't Hof MA, van ' $t$ Hof $B E$ Maltha JC. Putative golden proportions as predictors of facial esthetics in adolescents. Am J Orthod Dentofacial Orthop. 2008 0ct;134(4):480-3. doi: 10.1016/j.ajodo.2006.10.041.

\section{Laís Valencise Magri}

\section{(Corresponding address)}

Av. do Café s/n, Monte Alegre -14040-904,

Ribeirão Preto - Brazil

Phone/Fax: + 55 (16) 3315-4017

Date submitted: 2017 Jul 05

E-mail: laisvmagri@gmail.com 